\title{
Physics and politics: a happy marriage?
}

f) hysics and politics: at first sight an unhappy couple, but we should know better. Think of Angela Merkel, a physicist trained in the former East Germany but now the most powerful player in the European Union. As an independent mind in a slightly xenophobic Europe that is afraid of the migration of people from Syria, she is opening the borders of Germany and investing in housing and jobs. What can we learn from fellow physicist Angela Merkel?

First, let us keep in mind that immigration is the motor of history. Without immigration, Homo sapiens would still be in Africa, with Neanderthals' running Europe. Without immigration, the USA would still be a minor country without a global role. Second, integration is always tough to handle because it is based on a mind-set of 'us' versus the 'others'. Prejudice plays an important role in rejecting immigration. Third, when the first two steps have been taken, innovation is the result. Just look at the names of the founding fathers of successful startups like Facebook,

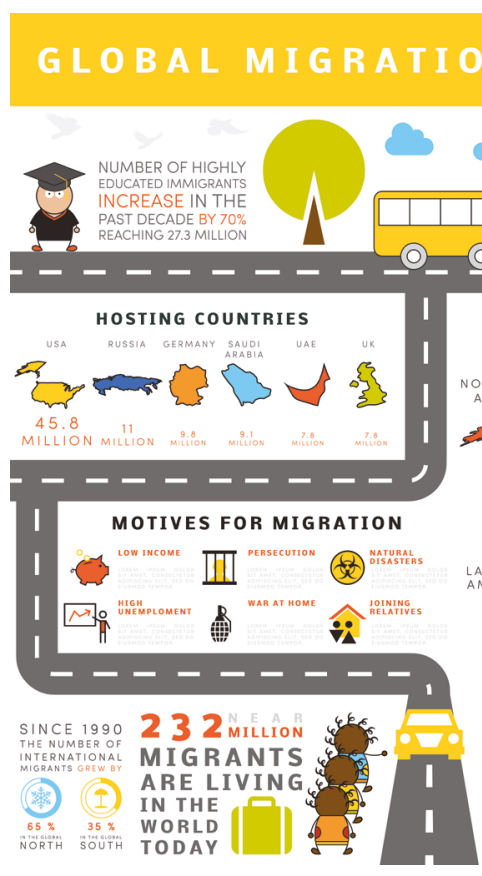
Google and Tesla, most of them do not go back to the founding fathers of the original colony.

Look at the USA with its huge waves of immigrants that were integrated in society. These immigrants were poor and lacked education in most cases, but were highly motivated to start a new life in uncharted territory. They imported a gene pool of DNA of entrepreneurship and daring. In my opinion this is the basis of the strong entrepreneurial spirit of the USA, as compared to Europe.
The 'haves' stayed at home, the 'have-nots' with guts left for the new frontier. Evolution is slow in its usual track; immigration with its strong and immediate selection of an entrepreneurial gene pool evolves at a faster pace in a country with new opportunities and new challenges.

In physics, immigration has also been very successful. In the northern European countries, a majority of the $\mathrm{PhD}$ students is from Eastern and Southern Europe, with Asia as a runner-up. The fraction of foreign PhD's in The Netherlands is close to 60 to $70 \%$. Most of them stay in The Netherlands, fully integrate and land in high-tech jobs at Shell, ASML or equivalent. Also in the USA physics depends heavily on a pool of foreign $\mathrm{PhD}$ students.

Do we in Europe want to miss out on this opportunity of opening our borders for a wave of highly motivated immigrants from Syria? Let us open our minds, not as charity but as wise people that accept the course of history and put it into perspective. Let us open up our economy to build new housing, incorporate this new work force and invest in schooling of their families. Immigration from Syria is not a problem but a challenge with a beautiful future.

EPS can help to speak its mind and remember society of the above message. Physics has a strong international tradition with full acceptance of scientists from all over the world. Physics helped many Jewish scientists to leave Nazi-Germany, a limited effort in numbers but a good example for society. Society would be better off with a few more of these values on its mind. 